\title{
A Comparative study on Dactylis slovenica Dom. and D. glomerata L.
}

\section{A. DOROSZEWSKA}

The great morphological variability in the genus Dactylis makes the study of the sys'ematics of this economically important genus of grasses very difficult. In most cases the variability is continuous and there are no traits clearly distinguishing the particular forms. Neither are there any sterility barriers so that the various formes can cross with each other giving fertile hybrids. The lack of clearly marked interspecific differences has been the cause of much inconsistency in the systematic treatment of this genus by various workers. The Dactylis forms which have been discriminated are defined by $s: m e$ florists as separate species and by others merely as subspecies. Cytological investigations have reavealed two chromosome levels within the genus Dactylis: one diploid with $2 n=14$ and the other tetraploid with $2 n=28$ (Levan 1930, $\mathrm{K}$ a t te rman 1931, M üntzing 1933 and 1937). In the course of an investigation on Dactylis $\mathrm{S}$ te b bins and $\mathrm{Zahory}$ (1959) reached the conclusion that the genus consists of one common species Dactylis glomerata L. in wh:ch two groups are discernable, one diploid the other tetraploid. They studied in detail the group of 11 diploid subspecies growing mainly in the Medierranean area and in South Europe.

The tetraplo:d forms of Dactylis spreading in Europe and Asia from the polar to the subtropical regions have a much wider distribution than the diploids. The tetraploids are a very numerous and variable group of plants which as yet is little known, though the first steps towards a detailed investigation have already been made. In 1961 Borrill distinguished the new tetraploid species Dactylis marina Borrill occuring along the Atlantic and Mediterranean coasts of Europe. The present investigation on $D$. slovenica mary also add some details to the knowledge of the tetraploid forms of Dactylis.

Dactylis slovenica was described by D om in in 1923 (D o m in 1929) as a new species occurring in the Carpathians on lime and dolomite substrata. At that time four main forms of Dactylis with distinctly different distributional areas were distinguished in Europe.

These forms were Dactylis glomerata L., D. Aschersoniana G $\mathrm{r}$ aie b n., 
D. hispanica Roth., and D. slovenica Dom. In $1943 \mathrm{Dom}$ in published a monography of the genus Dactylis in which he defined D. slovenica and all other above-mentioned forms as subspecies of D. glomerata L. In this way D. slovenica was degraded by its discoverer to the rank of a subspecies, but treated on equal terms with $D$. Aschersoniana and D. hispanica.

Domin discovered D. slovenica for the first time in the Belanske Tatry massif, which forms part of the Slovenian Tatras, whence the name $D$. slovenica. In further observations $\mathrm{D}$ om in found that $D$. slovenica was a montane plant growing in the Carpathian Mts. to the East Carpathian massif in the East and to the Karkonosze and Moravia in the West. In this anea it occur together with D. glomerata.

On the slopes of the Belanske Tatry massif D. slovenica grows in dense high tufts together wich such species as Cimcifuga foetida, Aruncus silvester, Aconitum firmum, Digitalis ambigua, Senecio Fuchsii, Mulgedium alpinum etc. The plants of $D$. slovenica are conspicuous by their vigorous growth habit. Their widely outspread and drooping panicles differ so much from the appearance of $D$. glomerata that at first sight they seem to constitute a very distant form. However, on closer examination the differences between $D$. glomerata and $D$. slovenica are seen to be less elearly marked and, therefore, the question arises whether $D$. slovenica is in fact a separate species, a subspecies or only one of the numerous modifications of D. glomerata. The investigation of the differences and the similarities between the two forms has been the aim of this work.

\section{MATERIAL AND METHODS}

The examinations of D. slovenica and D. glomerata were carried out on plants growing in their natural habitats and on plants transferred from their natural stands and cultivated in the Botanical Garden of the Warsaw University. The plants described by $\mathrm{D}$ om in as D. slovenica grew in the Belanske Tatry massif in the valley of the stream Regliany Potok near a locality called Siroke Pole. The altitude of the valley was about $1250 \mathrm{~m}$. above sea level and the soil limy. The plants for this investigation were collected in 1956 in the Belanske Tatry massif in the Holubyho Dolina valley the altitude of which was approximately the same as of the Regliany Potok valley. In his list of stands of D. slovenica in the Tatras Dom in 1943 also mentioned the Holubyho Dolina valley. Somewhat below the mountain shelter in this valley there is a small dell called the Dolina Sedmi Promenov where there are stands of typical D. slovenica. The living specimens of $D$. slovenica for this investigation were collected from four stands situated not far from each other in Holubyho Dolina valley. The firts of these stands was situated near the parth runnig just 
above the Sedmi Promenov waterfall at the altitude of $1350 \mathrm{~m}$, above sea level. On this stand besides the typical $D$. slovenia specimens there were also D. glomerata plants and natural hybrids between these two forms. The second stand was in the Dolina Sedmi Promenov dell near the waterfall at the altitude of $1275 \mathrm{~m}$. This stand was the dampest of all and D. slovenica plants growing there were very vigorous and morphologically uniform. The third stand was situated at the bottom of the Dolina Sedmi Promenov dell at the altitude of $1225 \mathrm{~m}$. Here, similarly as on the first stand, D. slovenica was growing together with D. glomerata and their hybrids. The fourth stand was situated in the Holubyho Dolina valley above the Dolina Sedmi Promenov dell at the altitude $1370 \mathrm{~m}$., on the south-east slope cleared of the forest which had once grown there. This stand was the driest of the four stands described here: the plants growing there abundantly were morphologically uniform.

The D. glomerata plants used as the comparative material for this investigation were collected from various lowland and mountain stands in Poland.

The list of these plants cultivated in our Botanical Garden used for the investigation was as follows:

D. slovenica:

no. 55 from stand 1 in the Tatras,

no. 56 to 60 from stand 2 in the Tatras,

no. 49 from stand 3 in the Tatras,

no. 43 to 45 from stand 4 in the Tatras,

no. 1 from Dolina Sedmi Promenov dell in the Tatras,

Natural hybrids $D$. slovenica $\times D$. glomerata:

no. 52, 53, 54 from stand 1 in the Tatras,

no. $46,47,50$ from stand 3 in the Tatras,

D. glomerata from mountains stands:

no. 51 , stand 1 in the Tatras,

no. 49 , stand 3 in the Tatras,

no. $63,64,65$, a rocky stand sparsely covered with mountain pine in the Morskie Oko valley in the Tatras,

no. 21 to 30 , a meadow near the Droga Pod Reglami road in Kiry near Zakopane,

no. 31 to 40, a meadow near the stream in Bukowina Tatrzańska Dolna,

D. glomerata from lowland stands:

no. $4,5,6,7$, open roadside stands in Salomea near Warsaw,

no. 11 to 20, stands in a this mixed forest in Zalesie near Warsaw,

no. $41,42,61,62$, the Puszcza Bialowieska forest,

no. 2, 3, seaside, thinly forested sand dunes in Leba on the Baltic Sea coast. 
In the Botanical Garden all the Dactylis plants were grown side by side under the same conditions, on clayey-soil beds with strong insolation! The plants were grown from 1956 to 1960. Every year they were mea-, sured, their bloomig seasons were recorded, and they were examined with regard to their vigour, pollen fertility etc.

The crosses were made by the methods of castration and of additional pollination.

The material for cytological examinations was fixed in $1: 3$ aceto-alcohol and stained in propriocarmine. Pollen fertility counts were made on smears stained in 1:1 acetocarmine with glycerine.

\section{THE MORPHOLOGY OF D. SLOVENICA AND D. GLOMERATA}

Dactylis slovenica is a montane species of the Carpathians occurring most abundantly on lime substrata in the Tatras. It grows in thin forests, on pastures, and on meadows reaching from the sub-Alpine to the sub-mountain stage. In its mountain distribution D. slovenica meets with D. glomerata, the latter species being able to grow at considerable alti-
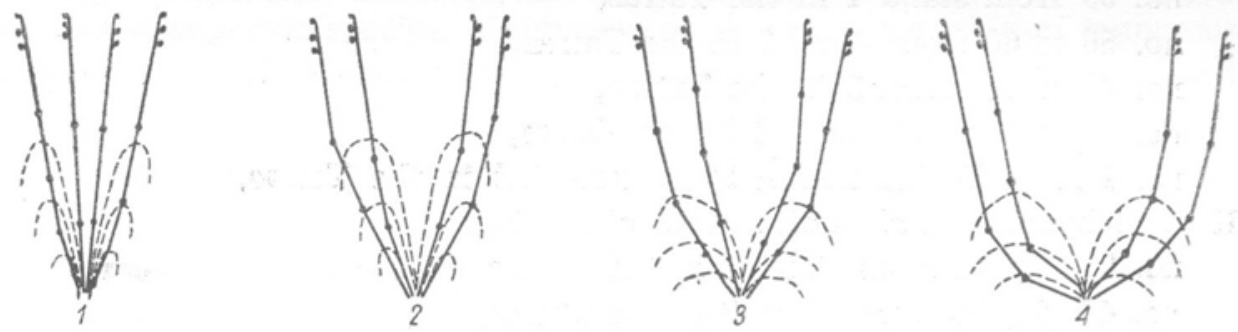

Fig. 1. Schematic diagrams showing the growth habits of Dactylis glomerata tufts: 1 - culms almost straight, leaves growing almost vertically with only the tips drooping; 2 - culms slightly bent in the nodes, leaves of the same kind as in 1; 3 - culms same as in 2, leaves bending outward; 4 - culms strongly arched, leaves bending outward

tudes in spite of its lowland origin. The highest altitude at which $\mathrm{Ko}$ tula (1889-90) found D. glomerata was $1707 \mathrm{~m}$. near Zimne Źródła in the Tatras. In the Alps D. glomerata was found at the altitude of $2320 \mathrm{~m}$. (H e g i 1907). A characteristic trait of D. glomerata is its great morphological variability and, therefore, to establish the systematic position of D. slovenica the morphology of the latter is here compared to the characteristic traits of the former. For this purpose many plants of D. glomerata coming from various parts of Poland were examined but in the compara- 
tive tables only the most typical individuals from the particular stands are described.

Growth habit. The plants of $D$. slovenica are vigorous, the culms are strong, thick, and slightly bent at the nodes so that the flower culms are arched.

In the case of $D$. glomerata four main types of the growth habit have been discriminated in the course of comparative examinations. The schematic diagrams of these four types are shown in fig. 1 . The growth habit of the tufts, as shown by these diagrams, depends on the magnitude of the bend in the nodes and on the position of the basal leaves which are either almost vertically upright with only the ends drooping or curved towards the ground. Between the four main types there are continuous series of intermediate forms.

The distribution of the growth habit types in D. glomerata and D. slovenica is shown in Table 1 . As is to be seen the variation of the growth habit of $D$. slovenica ranges between types 3 and 4 and is not as wide as the variation of $D$. glomerata.

Table 1

The types of the growth habit of tufts according to fig. 1

\begin{tabular}{|c|c|c|c|c|}
\hline \multirow{2}{*}{$\begin{array}{c}\text { No. } \\
\text { of plants }\end{array}$} & \multicolumn{4}{|c|}{ The types of the growth habit } \\
\hline & 1 & 2 & 3 & 4 \\
\hline D. slovenica & & & $\begin{array}{lll}44 & 56 & 57 \\
58 & 59\end{array}$ & $\begin{array}{l}1434548 \\
55\end{array}$ \\
\hline $\begin{array}{l}\text { D. glomerata } \\
\text { from lowland stands } \\
\text { from mountain stands }\end{array}$ & $\begin{array}{llll}23456 & \\
51 & & & \end{array}$ & $\begin{array}{lll}61 & 62 & \\
31 & 32 & 33 \\
36 & 37 & 40 \\
63 & 64 & 65 \\
49 & & \end{array}$ & $\begin{array}{lll}18 & & \\
34 & 35 & 38 \\
39 & & \end{array}$ & 4142 \\
\hline
\end{tabular}

The size of culms and leaves. The plants of $D$. slovenica are somewhat larger than the plants od D. glomerata, but the difference is not significant. The height of the culms in D. slovenica is about $1.5 \mathrm{~m}$., whereas among the D. glomerata plants there are much lower individuals, some of them less than one metre tall, e.g, plants no. 41 and 42 from the Puszcza Bialowieska forest, and individuals of the same size as D. slovenica, e.g. plants no. 2 and 3 from Lelba. The basal leaves of $D$. slovenica are about one metre long and their widths range 7 to $13 \mathrm{~mm}$., whereas the widths of the leaves on the culms range up to $15 \mathrm{~mm}$. In the most vigorous specimens of $D$. glomerata the length of the basal leaves is not 
more than $80 \mathrm{~cm}$. and the widths of these leaves range 4 to $12 \mathrm{~mm}$. This means that the basal leaves in D. slovenica are somewhat larger than in D. glomerata. However, in D. slovenica plants grown in the Botanical Garden in Warsaw the length of leaves gradually decreased and after three years of cultivation it was of the same onder as in D. glomerata. On the other hand, the height of the culms did not decrease and after five years of cultivation the maximum height of the culms in $D$. slovenica was $1.91 \mathrm{~m}$.

The length of the ligule ranges 3 to $8 \mathrm{~mm}$. in D. glomerata and 4 to $7 \mathrm{~mm}$. in D. slovenica.

The colour of plants. The plants of $D$. slovenica are usually bright green similarly as many specimens of $D$. glomerata from both mountain and lowland stands. In D. glomerata the colour of plants ranges from pale green - e.g. specimens no. 61 and 62 from the Puszcza Białowieska forest - throught bright green, to bluish-grewn and even grayish green as in the plants no. 2 and 3 from Leba. (Table 2).

Table 2

The colour of plants

\begin{tabular}{|c|c|c|c|c|}
\hline No. of plants & Pale green & Bright green & Bluish green & Grayish green \\
\hline D. slovenica & 5760 & $\begin{array}{rrrr}1 & 43 & 44 & 45 \\
55 & 56 & 58 & 59\end{array}$ & 48 & \\
\hline $\begin{array}{l}\text { D. glomerata } \\
\text { from lowland stands }\end{array}$ & 6162 & 4142 & 2029 & 23 \\
\hline from mountain stands & 31 & $\begin{array}{lll}32 & 33 & 40 \\
63, & 64 & 65\end{array}$ & $\begin{array}{lll}34 & 35 & 36 \\
37 & 38 & 39 \\
49 & 51 & \end{array}$ & \\
\hline
\end{tabular}

The stiffness and the harshness of plants. The stiffer plants usually are also harsher, since both these traits depend on the content of silica. L a c k a m p (1955) demonstrated that the D. glomerata plants containing more silica had more sharp toothlets on the margins and the ribs of leaves and were thus harsher to the touch.

Among the plants of $D$. glomerata four degrees of harshness have been discriminated: smooth, slightly harsh, harsh, and very harsh.

The plants of D. slovenica are smooth or slightly harsh (Table 3).

The swelling of the culm base. The base of culms in D. slovenica is distinctly bulbed. The swelling is caused by a thick reduced stem inside the base of the culm. Being hard and lignified these reduced stems act in a way a reinforcement of the culm bases, thus improving the attach- 
ment of the plants to the substratum. According to D o m in $(1929,1943)$ the swelling at the base of culms is the main morphological trait distinguishing $D$. slovenica from the other Dactylis species.

The bulb-like swelling at the culm bases in D. slovenica is well developed in old culms growing separately outside the tufts. The young

Table 3

The harshness of plants

\begin{tabular}{|c|c|c|c|c|}
\hline No. of plants & Smooth & Slightly harsh & Harsh & Very harsh \\
\hline D. slovenica & $\begin{array}{l}1434445 \\
5760\end{array}$ & $\begin{array}{l}485556 \\
59\end{array}$ & & \\
\hline $\begin{array}{l}\text { D. glomerata } \\
\text { from lowland stands }\end{array}$ & 6162 & 4142 & 18 & 23 \\
\hline from mountain stands & $\begin{array}{llll}31 & 32 & 33 & 34 \\
35 & 56 & 38 & 40 \\
63 & 64 & 65 & \end{array}$ & 37 & 4951 & 39 \\
\hline
\end{tabular}

culms and the culms growing inside the compact tufts are not bulbed. The reason for this may simply be the mechanical pressure of the neighbouring tightly packed culms which do not allow the swelling do develop.

The swellings on the culms of $D$. slovenica are up to $2 \mathrm{~cm}$. long and about $1.2 \mathrm{~cm}$ in diameter.

The plants of D. glomerata also have such a lignified culm, but it is much smaller than in D. slovenica. Its diameter is not more then $0.5 \mathrm{~cm}$. and, therefore, the culm base is usually even or only slightly swollım.

In connection with the presence of the swelling on the culm base in D. glomerata, though much smaller than in D. slovenica, the question had to be considered whether the difference between the two forms in the development of this trait was not caused by the greater thickness of the whole culms in D. slovenica. In order to obtain quan'itative data on this trait the thickness of the culms and of the swellings on them was measured. Accepting the diameter of the culm directly above the swelling as the independet variable $\mathrm{X}$ and the diameter of the swelling as the dependent variable $\mathrm{Y}$, the regression coeff:cent for both forms was calculated. The ten thickest culms were measured in ten individuals of D. slovenica and in ten of D. glomerata.

The calculated regression coefficient was $\mathrm{b}=1.88$ for $D$. slovenica and $b=1.19$ for $D$. glomerata. The differences between these crefficients are represented graphically in fig. 2 . 
The measurements and the calculated regression coefficients show that the swelling of the culm bases is much more developed in $D$. slovenica than in D. glomerata and that this trait does not depend on the difference in the thickness of the culms. The swelling of the culm base is certainly one of the most characteristic traits of D. slovenica.

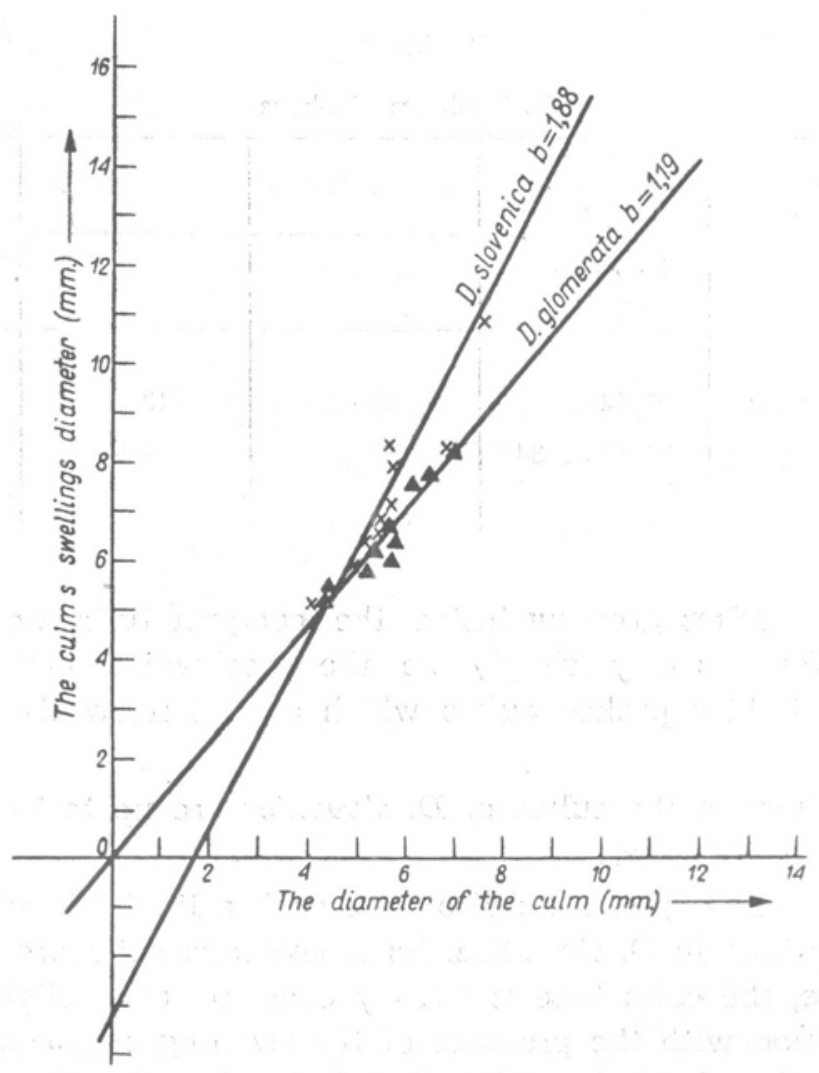

Fig. 2. Graph showing the regression of bulb diameter to culm diameter for $D$. slovenica and D. glomerata

The panicle. The differences in the structure of the panicles between $D$. slovenica and D. glomerata are considerable. The differences include the size, the proportions, and the drooping of the panicles.

The drooping of the panicle is caused primarily by the bend of the main axis and to a lesser degree by the downward recurving of the panicle branches appearing only in the large panicles with long branches.

The main axes of panicles in D. glomerata are differently curved. So far as the bend of the axis is concerned five types of panicles have been distinguished. They are shown schematically in fig. 3 . The first diagram shows the upright type of the panicle, the second an upright panicle with 
only the end drooping, the third a semi-crooping panicle, the fourth a drooping panicle, and the fifth a strongly drooping panicle. Besides the five main types shown in fig. 3 there are all kinds of intermediate forms. The drooping of the panicles in the particular tufts is not uniform and in each tuft there can be differently drooping panicles according to two or even three neighbouring types illustrated in fig. 3 . Therefore, in the case of this trait only its range of variation can be considered.

The panicles in $D$. slovenica are always drooping according to the types 3 to 5 in fig. 3 , though at the time of iblooming they are somewhat more erect.

The panicles in D. glomerata are erect varying within the range of types 1 to 3 . They usually are of type 1 , especially before and at the time of blooming. After blooming the most common panicles are of types 1 and 2 or even 3 . Panicles of type 1 after blooming are very rare. Table 4 shows the distribution of the D. slovenica and D. glomerata individuals according to the degree of drooping after anthesis.

From what has been said above it is apparent that both forms have drooping panicles, but in D. slovenica the trait is much mone strongly marked. Although, the ranges of variation of this trait in D. slovenica and
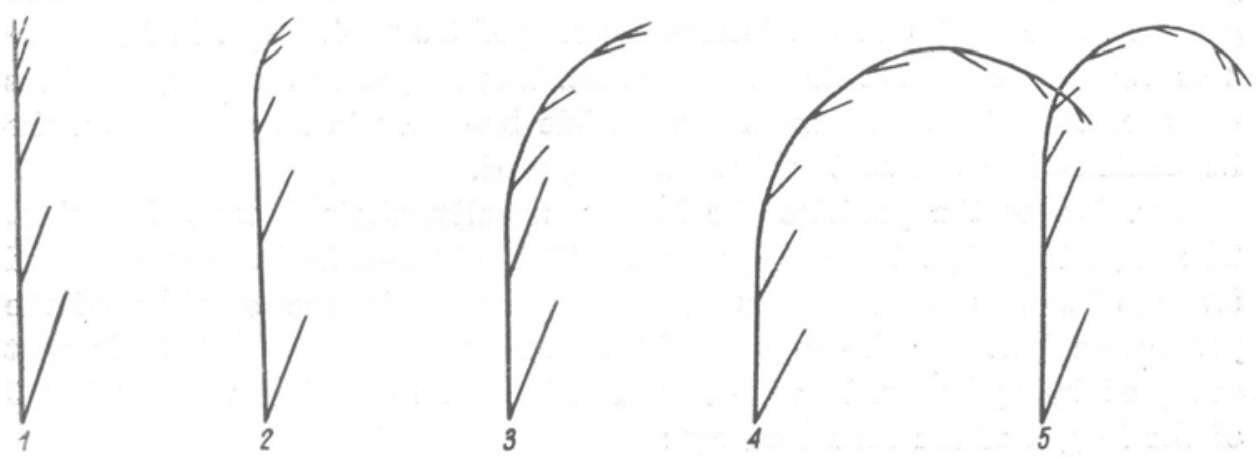

Fig. 3. Schematic diagrams showing the panicles in D. slovenica and D. glomerata: 1 and 2 - erect culms; 3 - semidrooping culm; 4 - drooping culm; 5 - strongly drooping culm

D. glomerata overlap, the drooping of the panicles can be accepted as one of the main traits distinguishing the two forms. The differences in this trait is the most distinct before anthesis, since then the panicles in D. glomerata are alvays erect and the panicles in $D$. slovenica are always drooping.

The size of panicles. The length of panicles in $D$. slovenica ranged 14.8 to $36.4 \mathrm{~cm}$., the average values for the particular individuals being 18.0 to $28.7 \mathrm{~cm}$. 
Table 4

The drooping of the panicles according to fig. 3

\begin{tabular}{|c|c|c|c|c|c|}
\hline \multirow{2}{*}{ No. } & \multicolumn{5}{|c|}{ The types of the drooping panicles } \\
\hline & 1 & 2 & 3 & 4 & 5 \\
\hline D. slovenica & & & 434459 & $\begin{array}{rrr}1 & 45 & 55 \\
56 & 57 & 58 \\
60 & & \end{array}$ & 48 \\
\hline $\begin{array}{l}\text { D. glomerata } \\
\text { from lowland } \\
\text { stands }\end{array}$ & 234142 & $\begin{array}{llll}18 & 61 & 62\end{array}$ & & & \\
\hline $\begin{array}{l}\text { from mountain } \\
\text { stands }\end{array}$ & $\begin{array}{lll}33 & 34 & 37 \\
49 & 51\end{array}$ & $\begin{array}{lll}32 & 35 & 38 \\
39 & 40\end{array}$ & $\begin{array}{lll}31 & 35 & 63 \\
63 & 64 & 65\end{array}$ & & \\
\hline
\end{tabular}

In D. glomerata the length of panicles ranged 9.3 to $23.0 \mathrm{~cm}$. and the average length for the particular individuals was 11.6 to $19.3 \mathrm{~cm}$. (Table 5).

The number of panicle branches was 5 to 7 in D. slovenica and 4.8 to 6.3 in D. glomerata. This small difference in the number of panicle branches coupled with the considerable differences in the length of panicles gives rise to an appreciable difference in th length of the internodes in panicles. The length of the internodes ranged 3.3 to $4.11 \mathrm{~cm}$. in $D$. slovenica and 2.3 to $3.3 \mathrm{~cm}$. in D. glomerata. The longer internodes and thus the greater distances between the panicle branches in $D$. slovenica make its panicles less compact and more outspread.

The longer the panicles the longer usually their lowest branches. The lowest panicle branches ranged 7.7 to $16.2 \mathrm{~cm}$. in D. slovenica and 5.7 to $7.9 \mathrm{~cm}$. in D. glomerata. Very interesting is the stability of the proportion between the length of the panicle branches and their part occup:ed by spikelets. The part occupied by the spikelets usually is $1 / 3$ of the length of the branches, e.g.:

No. of plant

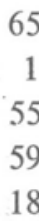

65

1

55

59

18
Length of the lowest panicle branch $\mathrm{cm}$
12.4

7.7

10.0

16.6

5.7
Length of part with spikelets $\mathrm{cm}$

3.8

2.7

3.8

5.2

2.2

The panicles in D. slovenica are distinctly longer than in D. glomerata and ow:ng to their longer internodes they are less compact. Often the panicles of $D$. slovenica have numerous secondary branchings and two 
or even three branches growing from one internode. The branching of the panicles in D. glomerata is never so profuse.

The spikelets. The differences between $D$. slovenica and D. glomerata in the structure of spikelets are not important. The spikele's are arranged in small bunches usually of four spikelets and the small bunches join together forming larger ones.

The length of spikelets ranged 6 to $8 \mathrm{~mm}$. in $D$. slovenica and 5 to $9 \mathrm{~mm}$. in D. glomerata. The number of flowers in a spikelet was 1 to 6 in D. slovenica and 1 to 7 in D. glomerata. As is to be seen in Table 5 one plant can have spikelets with a different number of flowers. This variation differs in the particular plants. The greatest difference was found in plant no. 49 which had six kinds of spikelets with $1,2,3,4,5$, and 6 flowers. The variation was smallest in plant no. 1 which had five flowers in all the spikelets. No significant difference was obsierved between $D$. slovenica and D. glomerata in the number of flowers in the spikelets. In both forms spikelets with three or four flowers predominated.

The ciliation of the spikelets is considered to be an important systematic trait of Dactylis glomerata (M üntzig 1937 p. 191 and 1943 p. 136). In the course of this investigation it was found that ciliation could be entirely absent or could occur in various degrees. Discrimination has been made between individuals which were glabrous slightly ciliated, ciliated, nad very strongly ciliated (Table 5).

In $D$. slovenica individuals with glabrous or slightly ciliated spikelets are the most common. This is in agreement with Domin's (1943) report in which on the ground of the ciliation of spikelets he defined D. slovenica from the Belanske Tatry massif as var. subglabra with two forms: f. atrichosantha having glabrous spikelets and f. trichosantha having slightly ciliated ones.

In the spikelets the cilia grow on the main rib of the glumes and sometimes also on the main rib of the lower lemma. The presence of the ciliation depending on the position of the spikelet in the bunch. Only the glumes and the lemmas situated on the outside of the bunches and not covered by other spikelets are ciliated.

The position of the spikelets in a bunch also affects the structure of the glumes: those lying on the outside of the bunches are always well developed, long, sometimes awned at the tip, with 1 to 5 ribs and the midrib ciliated, all green, and with only the margins membran us and sometimes frayed. The glumes covered by other spikelets are always badly developed, small and thin, without chlorophyl, and all membranous. The midrib often is difficult to distinguish. 
Tab

The panicles and the spikelets in $D$. slo

\begin{tabular}{|c|c|c|c|c|}
\hline $\begin{array}{c}\text { No. } \\
\text { of plants }\end{array}$ & $\begin{array}{l}\text { Length } \\
\text { of panicles } \\
\mathrm{cm}\end{array}$ & $\begin{array}{c}\text { A } \\
\text { Average } \\
\text { length of } \\
\text { panicles } \\
\mathrm{cm}\end{array}$ & $\begin{array}{l}\text { Length } \\
\text { of lowest } \\
\text { panicle } \\
\text { branches } \\
\mathrm{cm}\end{array}$ & $\begin{array}{l}\text { Average } \\
\text { length } \\
\text { of lowest } \\
\text { panicle } \\
\text { branches } \\
\mathrm{cm}\end{array}$ \\
\hline \multicolumn{5}{|l|}{ D. slovenica } \\
\hline 1 & $18,4-25,7$ & 20,1 & $6,2-11,5$ & 7,7 \\
\hline 48 & $16,0-20,8$ & 18,1 & $6,0-9,7$ & 7,7 \\
\hline 55 & $16,1-22,2$ & 20,4 & $6,6-12,0$ & 10,0 \\
\hline 56 & $14,8-22,5$ & 19,3 & $6,4-11,3$ & 9,5 \\
\hline 57 & $15,2-36,8$ & 26,6 & $6,0-18,7$ & 13,4 \\
\hline 59 & $23,1-38,2$ & 28,7 & $14,1-20,0$ & 16,2 \\
\hline 60 & $18,9-30,3$ & 25,3 & $9,4-16,9$ & 13,7 \\
\hline \multicolumn{5}{|l|}{$\begin{array}{l}\text { D. glomerata } \\
\text { from lowland } \\
\text { stands }\end{array}$} \\
\hline 2 & $12,9-18,0$ & 14,9 & $6,1-8,2$ & 7,2 \\
\hline 18 & $9,3-14,0$ & 11,6 & $4,2-8,0$ & 5,7 \\
\hline 41 & $10,1-19,3$ & 14,8 & $5,2-9,5$ & 7,9 \\
\hline 42 & $10,6-16,0$ & 13,5 & $4,5-8,6$ & 7,1 \\
\hline 61 & $14,1-23,0$ & 19,3 & $4,5-10,3$ & 7,2 \\
\hline 62 & $14,0-19,7$ & 17,2 & $5,4-9,3$ & 6,9 \\
\hline \multicolumn{5}{|l|}{ from Bukowina } \\
\hline 35 & $17,0-23,5$ & 19,3 & $8,5-11,7$ & 10,1 \\
\hline \multicolumn{5}{|l|}{$\begin{array}{l}\text { from Morskie } \\
\text { Oko }\end{array}$} \\
\hline $63-65$ & $19,1-30,3$ & 22,6 & $10,3-14,7$ & 12,4 \\
\hline \multicolumn{5}{|l|}{ Natural hybrids } \\
\hline 52 & $13,6-23,0$ & 18,5 & $5,8-12,5$ & 9,0 \\
\hline 53 & $13,9-24,4$ & 17,6 & $6,6-12,0$ & 8,4 \\
\hline 54 & $14,6-17,3$ & 15,8 & $7,0-9,2$ & 8,5 \\
\hline \multicolumn{5}{|l|}{ Artificial hybrids } \\
\hline 107 & $17,5-23,7$ & 21,0 & $8,8-12,8$ & 11,2 \\
\hline $106 / 2$ & $7,2-16,6$ & 12,9 & $3,7-7,9$ & 6,1 \\
\hline $106 / 3$ & $11,0-16,5$ & 14,2 & $5,4-9,0$ & 7,0 \\
\hline $106 / 4$ & $11,4-16,5$ & 14,1 & $5,2-8,1$ & 6,5 \\
\hline
\end{tabular}


le 5

venica, D. glomerata and their hybrids

\begin{tabular}{|c|c|c|c|c|}
\hline $\begin{array}{c}\text { B } \\
\text { Average } \\
\text { number of } \\
\text { panicle } \\
\text { branches }\end{array}$ & $\begin{array}{c}\text { A : B } \\
\text { Average } \\
\text { length of } \\
\text { panicle } \\
\text { internode } \\
\mathrm{cm}\end{array}$ & $\begin{array}{l}\text { Length } \\
\text { of spikelet } \\
\mathrm{mm}\end{array}$ & $\begin{array}{c}\text { Number } \\
\text { of flowers } \\
\text { in spikelets }\end{array}$ & $\begin{array}{c}\text { Ciliation } \\
\text { of spikelets }\end{array}$ \\
\hline & & & & \\
\hline 6,0 & 3,3 & $7-8$ & 5 & glabrous \\
\hline 5,0 & 3,6 & $6-9$ & 23456 & , \\
\hline 6,0 & 3,4 & $7-8$ & 2345 & , \\
\hline 5,5 & 3,5 & $7-8$ & 43 & $\begin{array}{l}\text { slightly } \\
\text { ciliated }\end{array}$ \\
\hline 6,9 & 3,8 & $6-7$ & 23 & ciliated \\
\hline 7,0 & 4,1 & $7-8$ & 123 & glabrous \\
\hline 6,0 & 4,3 & $6-8$ & 34 & $\begin{array}{l}\text { slightly } \\
\text { ciliated }\end{array}$ \\
\hline 5,0 & 2,9 & 7 & 345 & very ciliated \\
\hline 5,0 & 2,3 & $6-7$ & 123 & $\begin{array}{l}\text { slightly cil- } \\
\text { iated }\end{array}$ \\
\hline 5,1 & 2,9 & $6-7$ & 34 & glabrous \\
\hline 4,8 & 2,8 & $6-7$ & 34 & , \\
\hline 6,3 & 3,0 & $7-8$ & 67 & , \\
\hline 5,2 & 3,3 & $7-8$ & 45 & , \\
\hline 5,0 & 4,4 & $6-7$ & 1234 & $\begin{array}{l}\text { slightly cil- } \\
\text { iated }\end{array}$ \\
\hline 6,0 & 3,4 & $8-9$ & 34 & glabrous \\
\hline 5,3 & 3,5 & $5-8$ & $\begin{array}{lll}1234 & \end{array}$ & $\begin{array}{l}\text { slightly cil- } \\
\text { iated }\end{array}$ \\
\hline 5,3 & 3,3 & $5-7$ & 1345 & \\
\hline 4,9 & 3,2 & $5-8$ & 345 &, \\
\hline 6,0 & 3,5 & $6-7$ & 345 & $=$, \\
\hline 5,4 & 2,3 & $6-7$ & 345 &, \\
\hline 5,0 & 2,8 & $\begin{array}{l}7 \\
7\end{array}$ & 45 & glabrous \\
\hline 4,8 & 2,9 & 7 & 345 & $\therefore, \quad-1$ \\
\hline
\end{tabular}


The different possibilities in the development of the glumes according to the position of spikelets in the bunch are as follows:

1. in spikelets covering the bunch from the top both glumes are well developed and of the same length,

2. in spikelets with one side in and one out of the bunch the glumes are asymmetrical; the outside glume is well developed and the inner one covered by the other spikelets is reduced,

3 . the spikelets inside the bunch covered on all sides by other spikelets have both glumes reduced,

The spikelets inside the bunch are always glabrous even in strongly ciliated plants.

Contrary to the glumes the structure of the lemmas in Dactylis is always uniform.

The structure of the glumes and the lemmas in D. slovenica and D. glomerata is the same.

\section{EXPERIMENTS WITH THE CULTIVATED PLANTS}

The Dactylis plants were cultivated in the Botanical Garden in Warsaw from 1956 to 1960 . The observations and measurements carried out through all those years have shown that the individuals of $D$. slovenica have reaained their original growth habit and size during the five years of cultivation. This also applies to other traits, such as the harshness of the culms, the ciliation of the spikelets, the colour, the swelling at the culm base, the drooping of the panicles etc. The behaviour of the cultivated individuals of $D$. glomerata, whether brought from the lowlands or from the mountains, was the same.

The blooming season. The developmental cycle in $D$. glomerata is not uniform. There are races which flower early and races which flower late: this variability was already described by Turesson. (1929), Oldemeyer and $\mathrm{Hanson}$ (1955), Lackamp (1955), Kalton and Laffel (1955), and others. The blooming season is an important trait for the cultivation of grasses. The blooming of the lowland plants of D. glomerata cultivated in the Botanical Garden in Warsaw began at the end of May. The differences in the time of blooming between the particular tufts did not exoeed ten days.

The blooming of $D$. slovenica in the Tatras begins during the first half of July, the actual date depending on the local ecological conditions and the altitude of the stand. In the Botanical Garden in Warsaw the blooming season of $D$. slovenica was in the middle od June, i.e. a month earlier than in the Tatras but almost three weriks later than D. glomerata from the lowlands.

The specimens of D. glomerata brought from the Morskie Oko valley 
in the Tatras and some specimens ibrought from the mountain stands in Bukowina Tatrzańska flowered in the middle of June, similarly as D. slovenica. This means that the late blooming of $D$. slovenica is a trait characteristic of the montane plants in general and results from their somewhat later development than of the lowland plants. The slower rate of development is retained by the Dactylis individuals even when thery are cultivated for five years in the lowlands under different climatic conditions.

The D. glomerata plants no. 49 and 59 brought to the Botamical Garden in Warsaw from the Holubyho Dolina valley in the Taitras flowered simultaneously with the other individuals of D. glomerata from the lowlands. They must have been newcomers in the mountains and had still retained in their development the rhythm of the lowlands. This result confirms Professor Hádàc's personel communication that D. glomerata is not one of the natural constituents of the flora in the Holubyho Dolina valley and that the isolated individuals found in this valley must have been brought there by men and sheep.

The following plants were used for the crosses: D. slovenica plants no. 45 and 55, and the D. glomerata plant no. 41 from the Puszcza Białowieska forest. All the three plants were typical representatives of their forms. The chromosome number of these plants was 28. For the crosses the flowers wene castrated or additionally pollinated: the latter method was mostly used because castration in Dactylis plants is very difficult and ineffective. In additional pollination the panicles of both plants were placed under one isolator and in this way $\mathrm{F}_{1}$ seeds and selfs were simultaneously obtained from one panicle. The morphological traits of the hybrids and the selfs were sufficiently different to distinguish between them.

The following crosses were carried out by the castration method:

No. $106=55 \times 41$ giving 4 seeds and 3 seedlings.

No. $107=41 \times 55$ giving 4 seeds and 1 seedling.

The plants from these crosses were unquestionable hybrids. Their chromosome number was 28.

The additional pollination method was used for three crosses the results being as follows:

\begin{tabular}{r|c|c|c}
\hline \multirow{2}{*}{ No. of cross } & \multicolumn{3}{|c}{$\begin{array}{c}\text { Number of seedlings obtained } \\
\text { from the cross }\end{array}$} \\
\cline { 2 - 4 } & total & selfs & hybrids \\
\hline $108=41 \times 55$ & 24 & 9 & 15 \\
$105=55 \times 41$ & 22 & 9 & 13 \\
$109=45 \times 41$ & 16 & 3 & 13 \\
\hline Total & 62 & 21 & 41
\end{tabular}


As is to be seen the number of hybrids obtained with this method is twice the number of selfs, the reason being the partial self-sterility of the parental plants. The partial self-sterility in D. glomerata was reported by Nilss on (1934), Myers and Hill (1943), Oldemeyer and $\mathrm{H}$ a ns on (1955), and others. The results of the crosses in this investigation indicate that partial self-sterility occurs also in $D$. slovenica.

The morphology of the $F_{1}$ generation. Morphologically the $F_{1}$ generation was not uniform regardless of whether it was obtained by the method of castration or by the method of additional pollination. In the classification of the plants only the most characteristic traits of the parental plants were considered. These traits were: the swelling at the culm base, the date of blooming, the drooping of the panicles before and after blooming, and the appearance of the panicles outspread as in $D$. slovenica or compact as in D. glomerata.

The manner in which these traits occur in the parental plants and in the $F_{1}$ individuals is compared in Table 6 . The table list all the $F_{1}$ individuals obtained by the method of castration and some obtained by additional pollination, the individuals with different combinations of traits being selected in the latter case.

The data in the table show that the $F_{1}$ plants may have either a phenotype intermediate between the parental forms or some traits identical with one of the parental forms. The culm base may have no swelling or the swelling may be as thick as or smaller than in D. slovenica. In the hydrids the blooming season is retarded as in D. slovenica and semi-drooping panicles predominate. The semi-drooping panicles before anthesis may be erect or drooping after anthesis. The panicles may be outspread, compact, or intermediate. Various combinations of traits are also possible e.g. the plants with no swelling of the culm base may have drooping or semi-drooping and outspread panicles and on the contrary plants with a distinctly bulbed culm base may have erect and compact panicles as in D. glomerata.

This lack of uniformity in the $F_{1}$ generation points to the possibility of the independent inheritance of the particular traits and at the same time reflects the great phenotypic plasticity within the particular individuals.

The plants from the natural stands used for the crosses must have been heterozygotes with regard to the traits here considered.

The progeny obtained by selfing the two $D$. slovenica parent plants were uniform and identical with the parental plants. On the other hand the selfs of the D. glomerata parental plant differed from each other. It seems, therefore, that the main source of the lack of uniformity in the $F_{1}$ generation was the $D$. glomerata plant no. 41 used in the crosses. 
Table 6

The comparison the parental plants with the artificial and natural hybrids

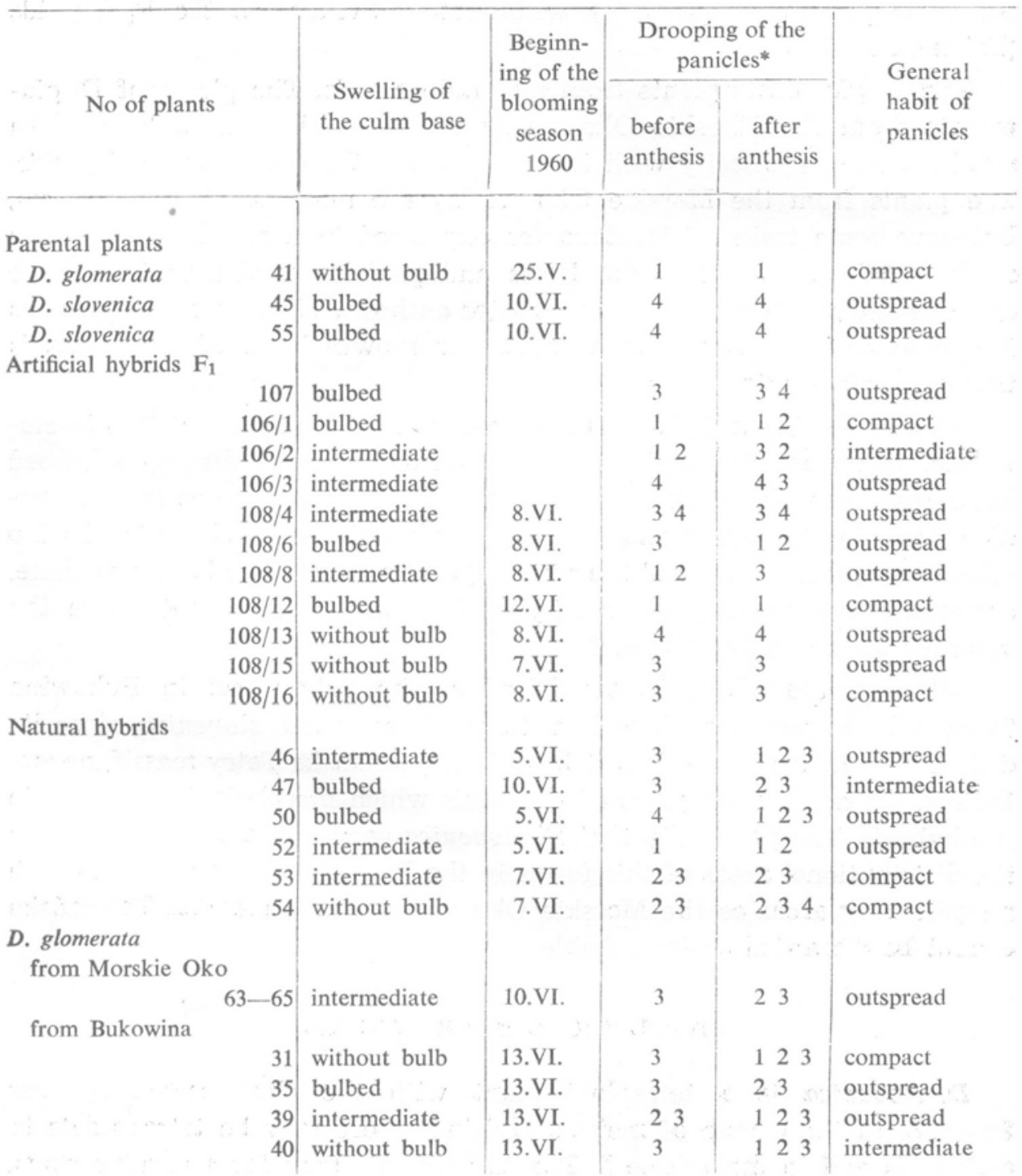

* According to fig. 3 .

Natural hybrids. The natural hybrids found in Holubyho Dolina in the Tatras closely resemble the $F_{1}$ hybrids obtained experimentally (Table 6). In the natural hybrids the swelling of the culm base may be small, intermediate, or well developed as in D. slovenica. Their blooming season is distincly retarded with regard to $D$. glomerata, but earlier than of D. slovenica. The panicles are usually semi-drooping and similarly as 
in the experimental $\mathrm{F}_{1}$ plants the panicles may be semi-drooping before anthesis and erect or drooping after anthesis. The natural hybrids manifest a. similar phenotypic plasticity within an individual as the $F_{1}$ hybrids (Table 6).

The D. glomerata plants from mountain stands. The plants of D. glomerata from the Morskije Oko valley and from Bukowina Tatrzańska manifest some similarity with the natural and the experimental hybrids. The plants from the Morskie Oko valley are morphologically uniform, but have some traits of $D$. slovenica expressed in a small degree. They all have slightly bulbed culm bases and panicles semi-drooping before anthesis and semi-drooping or erect after anthesis. The size of the panicles is similar as in D. slovenica, whereas the growth habit of the plants is that of D. glomerata (Table 6).

Səme plants from Bukowina Tatrzańska also are somewhat like D. slovenica. The most similar is the plant no. 35: it has a distinctly bulbed culm base, semi-drooping panicles of almost the same size as in D. slovenica and the vigorous growth habit characteristic for D. slovenica. In the other plants from this stand the swelling of the culm bases is intermediate, sometimes the panicles are semi-drooping and some plants have the vigorous growth habit (Table 6).

Although the plants in the Morskie Oko valley and in Bukowina Tatrzańska do not meet directly with specimens of $D$. slovenica, since its distribution in the Tatras is restricted to the Belanske Tatry massif, nevertheless, there are among them individuals which morphologicall resemble the hybrids. The possibility that $D$. slovenica genes were transferred from the distributional areas of this forms in the Belanske Tatry massif to such neighbouring areas as the Morskie Oko valley and Bukowina Tatrzańska cannot be discarded as improbable.

\section{CYTOLOGICAL EXAMINATIONS}

D. slovenica is a tetraploid plant with the chromosome number $2 \mathrm{n}=28$. In the course of meiotic divisions there may be tetravalents in diakinesis and in metaphase I. The tetravalents may form regular rings, rings twisted into the figure 8, or disrupted circles or chains. A similar occurrence of tetravalents was reported by Müntzing (1937) for D. glomerata. Only in one instance the Y arrangement of the chromosomes in a tetravalent was found.

The number of tetravalents in one cell in D. slovenica ranges 0 to 6 . Not one oell was found in which all the chromosomes would form tetravalents, but in all the plants an appreciable proportion of cells contained 14 regular bivalents. The proportion of cells in D. slovenica with 14 bi- 
valents in diakinesis ranged 16.9 to 24.5 per cent, whereas the average number of tetravalents in one cell was 0.97 to 1.43 . Besides the tetravalents and the bivalents the cells of $D$. slovenica may contain a few univalents and very rarely single trivalents (Table 7).

For comparison cytological examinations were also carried out on the D. glomerata plants no. $18,41,42,61$, and 62 . Similar chromosome arraingements were found in diakinesis. The average number of tetravalents in one cell was 0.96 to 1.28 and the proportion of cells with bivalents only ranged 20.0 to 33.3 per cent. Only the plant no. 2 from Leba strongly diverged from these average values: the average number of tetraivalents to one cell in this plant was 1.89 and only four cells with 14 bivalents were found in it. It is possible that these four cells were wrongly classified, because the distance between the chromosomes in late diakinesis is already considerable and the pairs are connected by one chiasma which often is almost invisible.

In the experimental $F_{1}$ hybrids (plants no. 105/18, 106/1; 106/2, and $106 / 3$ ) and in the natural hybrid (plant no. 47) the average number of tetravalents in one cell ranged 1.01 to 1.28 , whereas the proportion of cells with bivalents only was 15.0 to 33.3 per cent. These values were approximately the same as in the parental forms. Table 7 lists the numbers of tetravalents found in diakinesis of the pollen mother cells in D. slovenica, D. glomerata, and their hybrids. The table only lists the figure for euploid plants with 28 chromosomes.

The meiotic divisions in $D$. slovenica have an entirely regular course similarly as in D. glomerata. The meiotic divisions in all the pollen sacks of one flower are accurately synchronized.

However, deviations from the regular course of meiotic divisions have also been observed. In the 1st meiotic division there wene occasionally 1 or 2 univalents in a cell, but more than two univalents were never found. In anaphase of the 1st division the univelents could either remain on the equatorial plate and not be included in the telophase nuclei or they moved to the poles and were then included in the telophase nuclei. When each of two univalents moved to a different pole then each telophase nucleus contained 14 chromosomes. The chromosomes were counted in the metaphase of the 2nd division. In one instance at this stage the arrangement of 13 and 15 chromosomes was found: this arrangement was probably the result of the inclusion of two univalents in one telophase nucleus of the 1st division.

In the 1st meiotic division dividing univalents were quite often found. Their division usually was retarded with regard to the bivalents separating in anaphase. In metaphase of the 2nd division 14 and 15 chromosomes were found in some instances. This distribution must have been the result 
$\mathrm{Tab}$

The chromosome

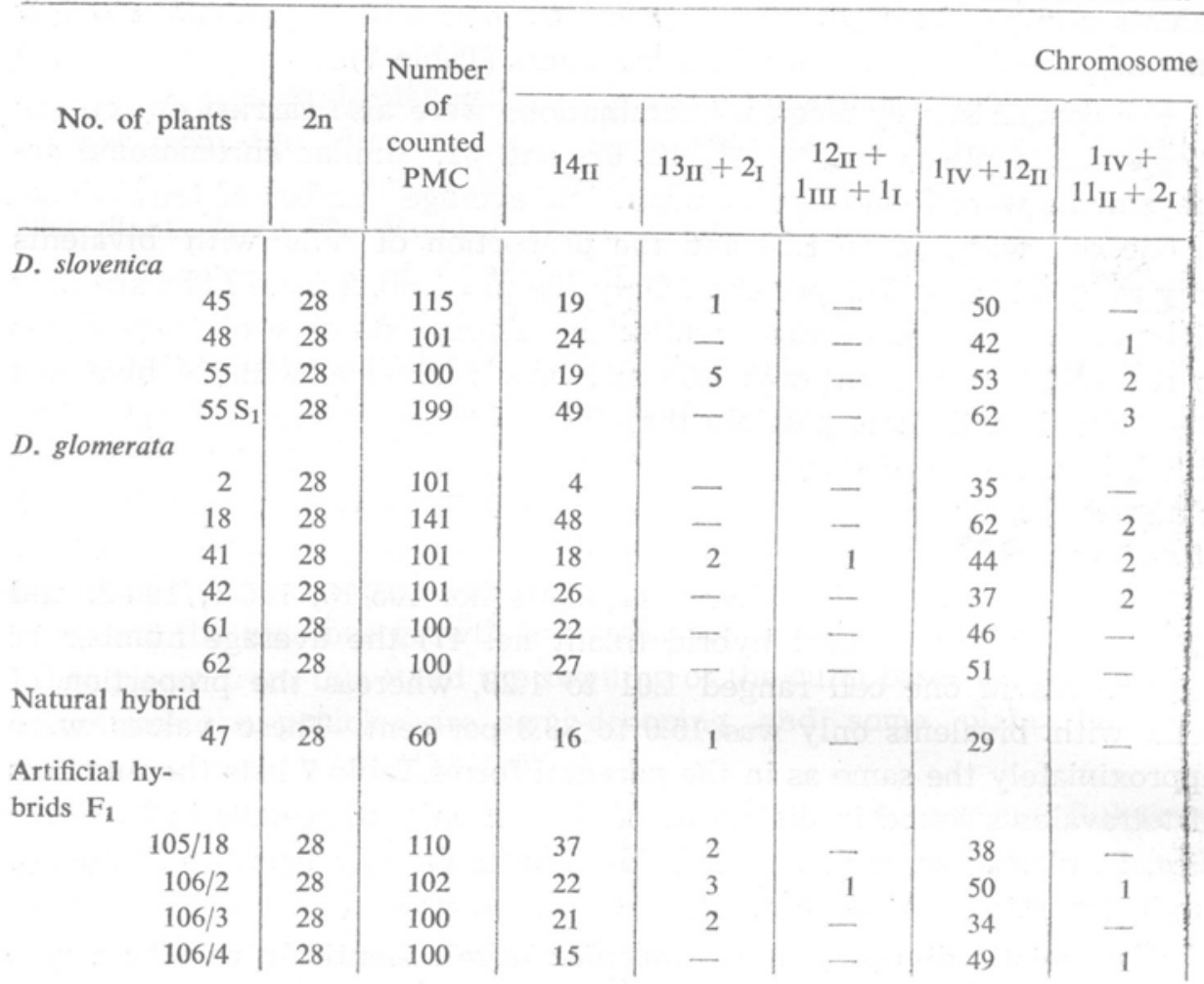

of the division of one univalent in the first meiotic division. The simultaneous division of both univalents was also often observed.

In the 2nd meiotic division chromosomes left on the plate and not included in the telophase nuclei were frequent. The number of such chromosomes could be one or more and they. were found in one as well as in both dividing cells.

In the tetrads additional micronuclei were sometimes found and they must have been formed from the chromosomes rejected in the 2 nd division.

The same irregularities in the meiotic divisions as those caused by the presence of univalents in D. slovenica - i.e. chromosomes lagging on the plate in the 2 nd division and the formation of micro-nuclei in the tetrads were also found in D. glomerata. This means that the deviations from the regular course of meiosis in D. slovenica are of the same kind as the irregularities in $D$. glomerata.

The pollen fertility counts in the Dactylis individuals grown in the Botanical Garden in Warsaw were made in three consecutive years (1958, 1959 , and 1960). The differences between the particular years were rather 
le 7

conjugation in diakinesis

\begin{tabular}{|c|c|c|c|c|c|c|c|c|}
\hline \multicolumn{7}{|c|}{ conjugation in diakinesis } & \multirow{2}{*}{$\begin{array}{c}\text { Average } \\
\text { number of } \\
\text { tetrava- } \\
\text { lents per } \\
\text { one PMC }\end{array}$} & \multirow{2}{*}{$\begin{array}{l}\text { PMC with } \\
\text { bivalents } \\
\text { only \% }\end{array}$} \\
\hline $\begin{array}{l}1_{\mathrm{IV}}+1_{\mathrm{III}} \\
+10_{\mathrm{II}}+1_{\mathrm{I}}\end{array}$ & $2_{\mathrm{IV}}+10_{\mathrm{II}}$ & $3_{\mathrm{IV}}+8_{\mathrm{II}}$ & $\begin{array}{c}3 \mathrm{IV}+ \\
7_{\mathrm{II}}+2_{\mathrm{I}}\end{array}$ & $4_{I V}+6_{I I}$ & $\begin{array}{l}5_{\mathrm{IV}}+ \\
+4_{\mathrm{II}}\end{array}$ & $\begin{array}{c}6_{I V}+ \\
+2_{I I}\end{array}$ & & \\
\hline - & 38 & 6 & - & 1 & - & - & 1,29 & 16,9 \\
\hline - & 28 & 6 & - & - & - & - & 1,15 & 24,0 \\
\hline - & 21 & - & - & - & - & - & 0,97 & 24,0 \\
\hline 1 & 51 & 18 & 1 & 12 & 1 & 1 & 1,43 & 24,5 \\
\hline- & 39 & 15 & - & 7 & 1 & - & 1,89 & 4,0 \\
\hline 1 & 16 & 10 & - & 1 & - & 1 & 0,96 & 33,3 \\
\hline - & 22 & 10 & - & 2 & - & - & 1,28 & 20.0 \\
\hline - & 28 & 7 & - & 1 & - & 一 & 1,18 & 25,7 \\
\hline- & 24 & 7 & - & 1 & - & - & 1,18 & 22,0 \\
\hline - & 18 & 4 & - & - & - & - & 0,99 & 27,0 \\
\hline- & 10 & 4 & - & - & - & - & 1,01 & 28,3 \\
\hline- & 23 & 9 & - & 1 & - & - & 1,04 & 33,6 \\
\hline- & 22 & 3 & - & - & - & - & 1,28 & 15,0 \\
\hline- & 33 & 10 & - & - & - & - & 1,02 & 24,8 \\
\hline- & 28 & 5 & 1 & 1 & - & - & 1.20 & 23,0 \\
\hline
\end{tabular}

small, i.e. of the order of two per cent. Pollen fertility in the individuals of $D$. slovenica ranged 77 to 95 per cent and the pollen fertility range of D. glomerata plants from the lowlands and from the mountains was the same. The pollen fertility in the natural and the experimental hybrids was in no way reduced and was about 90 per cent.

\section{DISCUSSION}

In the polyploid complex of Dactylis the tetraploid forms are much more common than the diploid ones. The tetraploids are characterized by great expansivity and a much greater morphological variability than the diploids.

This is primarily caused by the lack of sterility barriers which allows the exchange of genes between the diffenentiated forms thus inhibiting the differentiation processes within the genus. The exchange of genes may take place even between the diploid and the tetraploid populations (Müntzing 1937, Z a hory and Nur 1959). 
The other reason for the great variability of the tetraploids is their tetraploid condition owing to which some genes can occur four times. This has been demonstrated by $\mathrm{Brix}$ and $\mathrm{Quardt}$ (1953) for the gene $g$ determining the colour of leaves.

Many traits forming in D. glomerata continuous variation series e.g. the growth habit of plants and the drooping of the panicles - must be determined by numerous genes. An interesting characteristic of the genus Dactylis is the presence in this genus of diploid and tetraploid individuals which are morphologically undistinguishable (S t e b b in s and $\mathrm{Z}$ a hory 1959). This characteristic makes the classification of the genus very difficult. According to Dom in's (1943) classification the whole genus Dactylis is one compound species with seven subspecies and numerous forms. Domin's classification is based on morphological traits and disregards the cytological differences although, already in 1930 $\mathrm{L} \odot \mathrm{v}$ an reported that $D$. Aschersoniana is a diploid plant as distinguished from the tetraploid D. glomerata. Dom in, on the ground of morphological traits, assumed that the distribution of $D$. Aschersoniana extended over the whole of Poland. In the course of the present investigation plants morphologically identical with $D$. Aschersoniana were often found in central Poland, but they always had 28 chromosomes, whereas the diploid D. Aschersoniana probably occurs only in the beech forests of West Poland. In D o m i n's classification the plants with different chromosome numbers but morphologically identical are classified together as one subspecies.

$\mathrm{Stebbins}$ and $\mathrm{Z}$ ahory (1959) also consider the genus Dactylis tó be one compound species D. glomerata, but unlike Do mi n's classification their's is based on the chromosome number. Within the species D. glomerata they distinguish diploid and tetraploid subspecies. In this approach morphologically identical plants may be assigned to two different subspecies and the difficulties arising in this connection were pointed out by $\mathrm{Stebbins}$ and $\mathrm{Z}$ ahory themselves (1959).

All that has been said above clearly shows how differently the different workers approach the same phenomenon and what deplorable effects this has on the systematics of the genus Dactylis. The question thus arises what criterion should be given priority in the classification of the genus Dactylis, the morphology of the plants or the chromosome number?

The discrimination between diploid and tetraploid plants greatly facilitates the classification, but it seems illogical to assign to different systematic units plants morphologically identical, when within the diploid or the tetraploid forms the taxonomic units are discriminated according to the morphological traits alone. 
All this makes the' studies on the genus Dactylis a very difficult, but at the same time a very interesting problem, all the more so as the group of plants covered by the genus is still in the course of the gradual differentiation of the particular forms.

An example of this differentiation is provided by $D$. slovenica related with $D$. glomerata by many common traits. The morphological traits of both these forms are compared in Table 8. As is to be seen from this table $D$. glomerata has a much wider range of variation than $D$. slovenica.

The data assembled in Table 8 can be divided into three groups:

In the first group are the traits manifesting a continuous variation; in D. glomerata the range of variation is wide and in D. slovenica much narrower and contained within the limits of $D$. glomerata. These traits are the growth habit of the tufts, the colour and the harshness of the plants, the ciliation of the spikelets' the length of the ligule, and the number of flowers in a spikelet.

The second group also consists of traits with a continuous variation, but the overlapping of the variation ranges in D. glomerata and in D. slovenica is only partial and may differ in various degrees. The overlapping is wide in the case of the leaf widths and the maximum culm lengths, and narrow in the case of the average panicle lengths; the ranges of variation of the average lengths of internodes and of the drooping of panicles only contact.

The third group includes the contrasting traits, i.e. the swelling of the culm base or its absence and early or late blooming season. In the case of these traits the variation is discontinuous.

The late blooming of $D$. slovenica cannot be regarded as a systematic trait, since it is characteristic for all montane plants, but it is useful in the classification of plants.

The most important for distinguishing between the particular forms are the contrasting traits and for this reason the swelling of the culm base is the most characteristic trait of D. slovenica.

The drooping of the panicles and the length of the internodes also are useful traits for distinguishing between the two forms, because their ranges of variation are different, but these traits do not occur only in D. slovenica.

D. Aschersoniana has drooping and outspread panicles similarly as D. slovenica, however, the differences between these two forms are very great. D. Aschersoniana is a small frail plant, whereas D. slovenica is remarkable for its strong and vigourous growth habit. S z a fra n (1933) in the report on his investigations on the grasses of the pastures in the East Carpathians gives a detailed description and the measurements of 

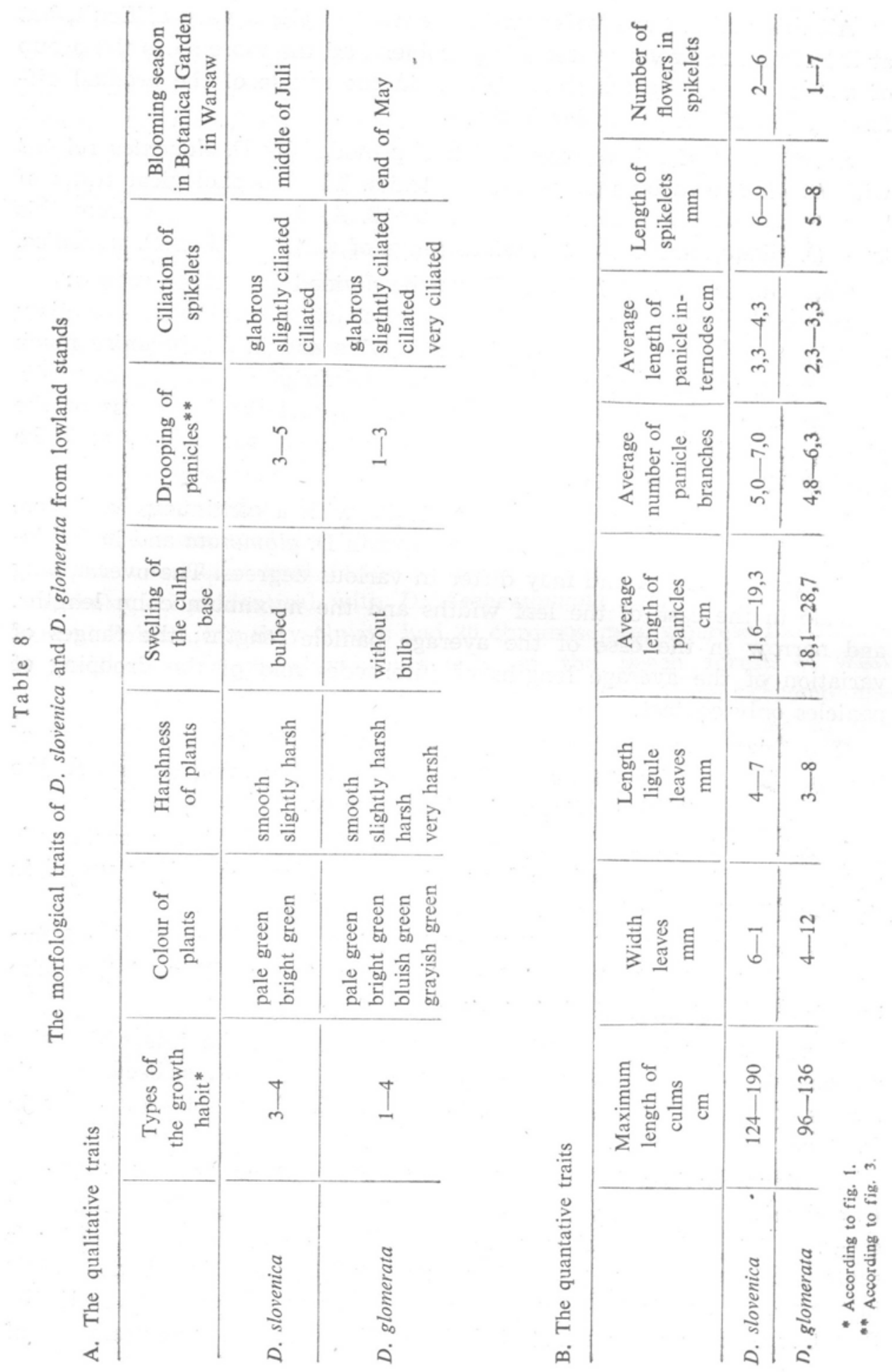
what he believed to be D. Aschersoniana, but the data in his report indicate that the plants he described could not have been $D$. Aschersoniana. They probably were $D$. slovenica which by its outspread and drooping panicles resembled $D$. Aschersoniana.

The analysis of morphological traits seems to indicate that $D$. slovenica has developed from $D$. glomerata. The two forms are connected by series of continuous variations indicating that $D$. slovenica is a relatively young form still in the course of differentiation out of the D. glomerata population.

On the other hand D. Aschersoniana is believed to be one of the ancestors of D. glomerata (M ün tzing 1937, M yers 1948, S teb bin s and $\mathrm{Z}$ a hory 1959) and therefore the genes determining the drooping of panicles could have been transferred from D. Aschersoniana through D. glomerata to D. slovenica.

Another alternative is that D. slovenica appeared in the Tatras as a result of a cross between D. glomerata and D. Aschersoniana and if this was the case the exchange of genes between these two species could have taken place through triploid hybrids. An exchange of genes of this kind was observed by $\mathrm{Z}$ ahory and $\mathrm{Nur}$ (1959) in Palestine where they found numerous triploids on the stands where the tetraploid and diploid Dactylis populations contacted. The chromosome number of some individuals in the progeny of these triploids was 28 .

Whichever of these possibilities is more accurate, D. glomerata is certainly the main ancestor of $D$. slovenica and the Taitra Mountains undoubtedly constituted a convenient ecological niche in which the new form could develop. The conditions prevailing in the mountains must have had a decisive influence on this process.

D. slovenica certainly arose as a Carpathian ecotype of D. glomerata, but its morphological uniformity and the rather well marked differentiation are sufficient to classify it as a distinct systematic unit. D o m i n (1943) was fully justified when he classified $D$. slovenica as a systematic unit of equai rank with $D$. Aschersoniana and D. hispanica.

The question whether $D$. slovenica is to be treated as an independent species or as a subspecies of $D$. glomerata depends on what systematic approach to the genus Dactylis is chosen. If Dom in's and S te b b in's opinion that the genus only consists of the compound species D. glomerata is accepted, then D. slovenica must be treated as a subspecies. But if other species than D. glomerata are discriminated in the genus, such as e.g. D. marina Borill, then D. slovenica also fully deserves the rank of an independent species.

Cytological examinations have revealed no differences between $D$. slovenica, D. glomerata, and their hybrids. In all instances the course of 
meiosis was similar and the average number of tetravalents in one cell was about one, which means that the level of tetravalents in $D$. slovenica is the same as in D. glomerata. These results confirm the earlier supposition that $D$. slovenica is a young form developed from the D. glomerata population and that it did not have time to become cytologically differentiated.

The values obtained in the course of this investigation for the level of tetravalents in $D$. slovenica and D. glomerata are very different from the data reported by other workers. The average number of tetravalents in one P.M.C. in D. glomerata was 3.5 according to M üntzing (1937), 2.8-4.4 according to $\mathrm{Myers}$ and $\mathrm{Hill}$ (1942), and 3.5 according to M c C o 11 u m (1958). The values reported by those workers are about three times the values obtained in this investigation. The difference probably arose owing to the high proportion of cells, more than 20 per cont, with bivalents only in the examined plants from the Tatras and the Polish lowland. This means that the differences in the level of tetravelents between the particular population of D. glomerata may be considerable.

M c Collum (1958) found that the distribution of tetravalents in the tetraploid forms of the genus Dactylis follows a bionomial curve. The result of this kind of distribution would be a constant level of about 3.5 tetravalents to one cell. McCollum found the same level of tetravalents in natural hybrids and in hybrids obtained experimentally by crossing two different forms. Nevertheless, in a few instances a lower average number of tetravalents in one cell was recorded.

It seems, therefore, that the average number of 3.5 tetravalents in on P.M.C. is the initial number for the tetraploid Dactylis plants. In some populations a reduction in the number of tetravalents and a corresponding rise in the number of bivalents takes place. This kind of chromosome behaviour is characteristic for segmental alloploids and makes possible further evolutional changes in the genus Dactylis.

\section{CONCLUSIONS}

1. Dactylis slovenica is a tetraploid with the chromosome number $2 \mathrm{n}=28$ growing on limy substrata in the Carpathians.

2. D. slovenica crosses easily with $D$. glomerata giving fertile hybrids.

3. The course of meiosis in D. slovenica, D. glomerata, and their hybrids is the same. The average number of tetravalents in one P.M.C. in $D$. slovenica ranges 0.97 to 1.29 . Similar numbers of tetravalents were found in D. glomerata and in the hybrids of the two forms. 
4. D. slovenica must have developed out of D. glomerata the two forms being related by many common traits which differ only by their range of variation.

5. The main traits distinguishing $D$. slovenica from $D$. glomerata are the bulbed culm base and the drooping outspreard panicles of the former form.

6. The plants of $D$. slovenica are morphologically rather uniform: they can be classified as a subspecies of D. glomerata on equal terms with the other already distinguished diploid and tetraploid subspecies.

The author is much indebted to Professor Dr. W. G a jews ki for his generous help and guidance in the course of this work.

\author{
Department of Genetics \\ Warsaw University \\ Varsaw, Poland, Al. Ujazdowskie 4
}

(Entered: 30.3 .1961$)$

\title{
REFERENCES
}

Borril1 M., 1961, Dactylis marina Borrill, sp. nov., a natural group of related tetraploid forms, J. Linn. Soc. (Bot.) 56: 431-439.

Brix K. und Quadt F., 1953, Experimentell genetische Untersuchungen über die Natur einer natürlichen Polyploiden, Z. Pflantzenzucht, 32: 402-420.

Domin K., 1929, Schedae ad floram Cechoslovenicam exsiccatum, Acta Bot. Bohem. 8: 50-51.

Domin K., 1943, Monograficka studie o rodu Dactylis L, Acta Botanica Bohemica 14: 3-147.

Dost a 1 J., 1950, Kwětena CSR, Praha.

Hegi G., 1907, Illustrierte Flora von Mittel-Europa, 1: 294-296.

Kalton R. R. and Leffel R. C., 1955, Evaluation of combining ability in Dactylis glomerata L., III. General and specific effects, Agron. Journ. 47: 370-373.

Kattermann G., 1931, Ubber die Bildung polyvalenter Chromosomenverbände bei einigen Gramineen, Zeitsch. f. wiss. Biol, Abt. E., Planta 12: 732-774.

Kotula B., 1889-1890, Rozmieszczenie roślin naczyniowych w Tatrach, Kraków.

La ckamp J. W., 1955, On the determination of harshness in plants of cocksfood, Euphytica $4: 31-33$.

Levan A., 1930, Beitrag zur Kenntnis der Chromosomen in der Gattung Dactylis L., Botan. Notiser: 95-104.

M c Collum, 1958, Comparative studies of chromosome pairing in natural and induced tetraploid Dactylis, Chromosoma (Berl.) 9: 571-605.

Müntzing A., 1933, Quadrivalent formation and aneuploidy in Dactylis glomerata, Botan. Notiser: 198-205.

Müntzing A., 1937, The effects of chromosomal variation in Dactylis, Hereditas, 23: $112-235$.

Müntzing A., 1943, Characteristic of two haploid twins in Dactylis glomerata, Hereditas 29: 134-140. 
Myers W. M., 1943, Analysis of variance and covariance of chromosomal association and behavior during meiosis in clones of Dactylis glomerata, Bot. Gaz. 104: $541-552$.

M y ers W. M., 1948, Studies on the onigin of Dactylis glomerata L., Genetics 33: 117 .

Myers W. M. and Hill H. D., 1942, Variation in chromosomal association and behavior during meiosis among plants from open pollinated populations of Dactylis glomerata L., Bot. Gaz. 104: 171-177.

Myers W. M. and Hill H. D., 1943, Increased meiotic irregularity accompanying inbreeding in Dactylis glomerata L., Genetics 28: 383-397.

Nilsson-Leissner G., 1942, A case of increased vitality in sibpollinated later generations of self-fertilised Dactylis glomerata strains, Hereditas 28: 222-224.

Oldemeyer D. L. and Hansan A. A., 1955, Evolution of combining ability in orchard grass Dactylis glomerata L., Agron. Journ. 47: 158-162.

Stebbins G. L., 1956, Cytogenetics and evolution of the grass family, Am. Journ. of Botany 43: 890-905.

Stebbins G. L. and $\mathrm{Z}$ ahory D., 1959, Cytogenetic and evolutionary studies in the genus Dactylis. I: Morphology, distribution and interrelationships of diplaid subspecies, Univ. Calif. Publ. Bot. 31: 1-40.

Turesson G., 1929, Ecotypical selection in siberian Dactylis glomerata, Hereditas 12: $335-351$.

Sza fran B., 1933, Badania nad trawami pastewnymi Karpat Wschodnich. I. Kupkówka Aschersona (Dactylis Aschersoniana Graebn.), Puławy.

$\mathrm{Z}$ a hory D. and $\mathrm{Nur}$ U., 1959, Natural triploids in the orchard grass Dactylis glomerata L., polyploid complex and their significance for gene flow from diploid to tetraploid levels, Evolution 13: $311-317$. 